\title{
Prevalence and epidemiological correlates and treatment outcome of HCV infection in an Italian prison setting
}

Micaela Brandolini ${ }^{1}$, Stefano Novati ${ }^{1}$, Annalisa De Silvestri ${ }^{2}$, Carmine Tinelli ${ }^{2}$, Savino Francesco Antonio Patruno ${ }^{3}$, Roberto Ranieri ${ }^{4}$ and Elena Seminari ${ }^{{ }^{*}}$

\begin{abstract}
Background: The aim of the present study is to test in the feasibility of a screening programme for HCV infection in an Italian prison and to evaluate the treatment outcomes.

Method: Single-centre cross-sectional study carried out in Milan-Opera. The HCV infection prevalence was calculated on the imprisoned population on the January 31 2006, the data on treatment over the following 2 years. Treatment option offered to HCV chronically infected patients was then analysed, reasons for not being treated was evaluated.

Results: Of the 965 inmates, 695 were enrolled in the study, 682 (98\%) were males, the median age was 43 years. There were 131 (18.8\%) foreigners and 564 (81.2\%) Italians. HCV seroprevalence was 22.4\%(95\% Cl:19.4\%-25.7\%), 60 subjects (38.4\%) being HIV co-infected too. Prevalence of HCV infection was significantly higher in HIVAb positive (89.6\%; 95\% Cl:79.7\%-95.7\%) than in HIVAb negative (15.15\%; 95\% Cl 12.6\%-18.3\%) ( $p<0.001)$. Among Italian inmates HCVAb positivity was significantly higher than among foreigners $(p=0.0154)$. Among HCVAb positive patients, 135 subjects were HCV-RNA positive. Forty-seven (36\%) had major clinical contraindication to treatment, 18 (13\%) refused the treatment, 7 (5\%) moved to other Institute and 27 (20\%) were not evaluated by infectious disease specialists. Fifteen patients (43\%) who received treatment were considered responders, 9 (26\%) were non responders/relapsers, 6 (17\%) interrupted treatment due to side effects and $5(14 \%)$ were released during treatment and lost in follow-up.
\end{abstract}

Conclusions: This study indicates that the proportion of patients in a prison setting receiving diagnosis and treatment for HCV infection remained low.

Keywords: HCV-infection, HCV-prevalence, Prison, HCV treatment, HIV-HCV coinfection

\section{Background}

$\mathrm{HCV}$ infection in prison inmates is widespread, surveys in correctional system show an HCV sero-prevalence ranging from $16 \%$ to $42 \%$ in U.S.A. [1], $30 \%$ to $50 \%$ in European Countries [2] and $31 \%$ to $38 \%$ among Italian inmates [3,4].

As a consequence, several national authorities published guidelines which recommend testing each incoming inmate for blood transmitted diseases. In the 16/04/2000 act issued to preserve health in correctional settings [5], the

\footnotetext{
* Correspondence: e.seminari@smatteo.pv.it

${ }^{1}$ Clinica di Malattie Infettive, Fondazione IRCCS Policlinico San Matteo, Viale Camillo Golgi 19, 27100 Pavia, Italy

Full list of author information is available at the end of the article
}

Italian Ministry of Health made it necessary not only to test and treat all intra-venous drug abuse associated infections but also to promote educational programs to improve prison inmate awareness on preventive measures and therapeutic needs, as a result $\mathrm{HCV}$ screening should be offered to all inmates at admission. On the other hand, in a real life setting, due to a complex array of local (in jail) and national (Italian Ministry of Justice) organization deficits, not always are inmates routinely tested for either hepatitis virus and human immunodeficiency virus (HIV). An overwhelming number of daily incoming prisoners, a shortage of adequate health facilities and trained staff, continuous recirculation of inmates among prisons located in Italy, a
C Biomed Central

(C) 2013 Brandolini et al.; licensee BioMed Central Ltd. This is an open access article distributed under the terms of the Creative Commons Attribution License (http://creativecommons.org/licenses/by/2.0), which permits unrestricted use, distribution, and reproduction in any medium, provided the original work is properly cited. 
lack of a national health database of restricted subjects are the main reasons which hindered the carrying out of proposed acts.

Data on treatment of HCV chronic hepatitis in prisons are limited to few observational studies [6-8], small case series have been published in Italy on this specific topic [9]. In general, only a minority of patients with hepatitis $\mathrm{C}$ in prison can complete a full course treatment as early patient's release or side effects or concomitant pathologies have limited the access to treatment $[7,8]$.

The object of this study was firstly to evaluate the prevalence of HCV infection among prisoners and its epidemiological correlates, secondly to estimate the number who could be treated and HCV infected inmates who were actually treated, thirdly to calculate the number of sustained virologic responders among those treated.

\section{Methods}

The study was designed as a single-centre cross-sectional study and was conducted among inmates of a single, large North Italian prison (Milan-Opera) where the vast majority of inmates had been sentenced for a period longer than three years. This prison was built to contain 750 inmates, but actually more than a thousand (roughly 1200) people are normally detained. It is split into male and female sections (this last section was closed in 2010) with an inner Clinical Centre with one medical ward, and an isolation area for air born infection and two AIDS-wards.

Prevalence of $\mathrm{HCV}$ infection was calculated on the imprisoned population on the January 31 2006, data on treatment during the following 2 years. Data collection was carried out in two steps. Firstly, all the inmates sanitary records were reviewed to asses HCV sero-status. Secondly, all the subjects either untested or with a previous negative result of more than three years underwent HCV serology. Among patients with positive HCV serology, it was evaluated the prevalence of blood HCV RNA determination. Treatment option offered to HCV chronically infected patients was then analysed, reasons for not being treated was also evaluated. Lastly, among those treated, percentages of responders and non responders to treatment were analysed.

The Ministry of Justice study approved the study and granted an official waiver to proceed as data were collected in accordance with the ethical standards, guaranteeing the anonymity of the results. All participants signed an informed consent.

\section{Statistical analysis}

Categorical variables were described by means of count and percentage, continuous ones by means of median and range or interquartile range. Prevalence were given together with their 95\% confidence interval (95\% CI). Baseline patients characteristics (age, gender, nation of birth and HIV/HBV coinfection) were described for the overall sample and according to HCV infection. The Student's $t$ test was used to compare continuous variables and the Chi-square test was used to study the association between categorical variables.

Logistic regression model was fitted with $\mathrm{HCV}$ infection as dependent variable and nationality and age as independent variables. The statistical analysis was performed using Stata v11 (StataCorp, College Station, TX, USA).

\section{Results}

Of the 965 inmates in Milan-Opera prison the day of surveillance, 695 were enrolled in the study (either were already tested for $\mathrm{HCV}$ in the previous three years (439 pts; $45.5 \%$ ) or accepted to perform serological test (256 pts, $26.5 \%)$. Among the remaining 270 (28\%) patient not tested, 137 resulted to be released at the time of blood test, 36 moved to another prison, 59 denied the consent to participate to the study, 1 patient deceased and 3 resulted to be not tested despite they gave consent. For the remaining 34, the reason of not being tested was unspecified. No demographic differences were observed between those tested and not tested for HCV infection (Table 1).

Demographic characteristics of the 695 inmates tested are summarized by Table 2. Percentages of women and foreigners are comparable with those of Italian prisoner's population, respectively $<5 \%$ and $13 \%$ [10].

HCV seroprevalence was $22.4 \%$ (95\% CI: $19.4 \%-$ 25.7\%) - 156 subjects- with 60 subjects (38.4\%) being HIV co-infected too (Table 2). Prevalence of HCV infection was significantly higher in HIVAb positive $(89.6 \%$; 95\% CI: $79.7 \%-95.7 \%)$ than in HIVAb negative (15.15\%; 95\% CI 12.6\%-18.3\%) ( $<<0.001)$. Median CD4+ cell count in $\mathrm{HIV} / \mathrm{HCV}$ confected subjects was 351 cell/ $\mathrm{mm}^{3}$ (interquartile range: $198-492 \mathrm{cell} / \mathrm{mm}^{3}$ ).

Out of the 564 Italian inmates, 137 (24.5\%; 95\% CI 20.8\%-28.0\%) were HCVAb positive, among foreigners $19 /$ 131 were HCVAb positive (14.5\%; 95\% CI: 9.0\%-21.7\%); namely $12(20.3 \%)$ out of 59 African inmates, 3 (6.4\%) out of 47 from East-Europe and 4 (16\%) out of 25 LatinoAmerican were HCVAb positive. Among Italian inmates HCVAb positivity was significantly higher than among foreigners $(\mathrm{p}=0.0154)$, this association remained statistically significant after correction for age (OR 2, 95\% CI 1.2-3.4; $\mathrm{p}<0.01)$. In Italian inmates, HCVAb positivity was higher in age classes between $35-42$ and $43-52$ years (37\% and $28.7 \%$, respectively) while was lower in age classes between 18-34 and 53-82 (18 and 12\%, respectively), ( $<<0.001)$. Out of the 13 women tested for HCVAb, 8 (61.5\%) were positive. Among HCVAb positive patients, 135 subjects were HCV-RNA positive, 28 were HCV RNA negative and 13 did not perform any HCV RNA test (7 early release, 6 unknown) (Figure 1). Thirty-five (26\%) subjects among those HCV RNA positive were evaluated by infectious disease specialist and were elected to receive treatment with 
Table 1 Demographic characteristics of patients tested and not tested for HVC Ab

\begin{tabular}{|c|c|c|c|c|}
\hline & All $\mathrm{N}=965 \mathrm{~N}(\%)$ & Tested for HCV infection $\mathrm{N}=695 \mathrm{~N}(\%)$ & Not tested for HCV infection $\mathrm{N}=270 \mathrm{~N}(\%)$ & $\mathbf{p}$ \\
\hline Age mean (sd) & $43.59(11.99)$ & $43.2(11.18)$ & $44.58(13.83)$ & 0.11 \\
\hline Males & $944(97.82)$ & $682(98.13)$ & $262(97.04)$ & 0.33 \\
\hline Females & $21(2.18)$ & $13(1.87)$ & $8(2.96)$ & \\
\hline \multicolumn{5}{|l|}{ Origin } \\
\hline Africa & $92(9.53)$ & $59(8.49)$ & $33(12.22)$ & 0.23 \\
\hline East Europe & $67(6.94)$ & $47(6.76)$ & $20(7.41)$ & \\
\hline Italy & $775(80.31)$ & $564(81.15)$ & $211(78.15)$ & \\
\hline other & $31(3.21)$ & $25(3.6)$ & $6(2.22)$ & \\
\hline
\end{tabular}

IFN and ribavirin. Forty-seven (36\%) had major clinical contraindication to treatment (i.e. mental illness, cirrhosis, cardiac disease, low CD4+ cell count in HIV+ subjects), 18 (13\%) refused the treatment, 7 (5\%) moved to other Institute and 27 (20\%) were not evaluated by infectious disease specialist. Fifteen patients $(43 \%)$ who received treatment were considered responders, 9 (26\%) were non responders/ relapsers, 6 (17\%) interrupted treatment due to side effects and $5(14 \%)$ were released during treatment and lost to follow-up.

\section{Discussion}

The present study highlights the difficulties encountered in a screening process for $\mathrm{HCV}$ in a prison setting, despite dedicated personnel to this specific duty, roughly $30 \%$ of subjects did not receive the screening test, eventually only a minority of them denied the consent to participate. The problem of $\mathrm{HCV}$ infection in prison is extensive and troublesome, but both in US and in Europe $[11,12]$, according to directives, correctional facilities should seriously cope with the problem of HCV infection. The CDC estimates that $12 \%$ to $35 \%$ of US inmates had chronic $\mathrm{HCV}$ infection [12], the majority of these patients being represented by IVDU and/or tattooing $[13,14]$. According to different studies, the burden of $\mathrm{HCV}$ infected prisoners in Italy varies between 20 and $40 \%$, therefore considering an inmate average number of 65000 [10], roughly 10000 to 20000 patients in prison potentially need treatment (considering that roughly the $20 \%$ of patients testing antibody positive doesn't need treatment). These data emphasize the importance of surveillance in prison [15], and counseling of patients affected from HCV infection about prevention strategies and treatment options $[7,8]$.

The difficulties associated with HCV screening procedures in a prison setting as Opera is, are principally related to severe limitation due to a complex array of problems. First, institutional regulations and organization which cause the mobility of prisoners, who are moved from prison to prison for different reasons such as trial in cities far from the residence prison. Second, logistic problems (i.e. all the blood examination are performed outside the prison, and require time-expensive procedures to be activated) which translate into long time span between the HCV test prescription and its execution. As a consequence, despite it should be mandatory to test for hepatitis viruses and HIV

Table 2 Demographic characteristics of patients HVC Ab posivite vs HCV Ab negative patients

\begin{tabular}{|c|c|c|c|c|c|}
\hline & All N=695 N(\%) & HCV neg $N=539 \mathrm{~N}(\%)$ & HCV pos $\mathrm{N}=156 \mathrm{~N}(\%)$ & $p$ & $p^{*}$ \\
\hline \multirow[t]{3}{*}{ Age mean (sd) } & $43.2(11.18)$ & $43.34(11.71)$ & $42.71(9.14)$ & 0.53 & OR 0.24 \\
\hline & & & & & $95 \%$ Cl 0.97-1.01 \\
\hline & & & & & $P=0.24$ \\
\hline Origin & & & & & OR 2 \\
\hline Africa & $59(8.49)$ & $47(8.72)$ & $12(7.69)$ & & $95 \%$ Cl 1.2-3.4 \\
\hline East Europe & $47(6.76)$ & $44(8.16)$ & $3(1.92)$ & 0.03 & $p<0.01$ \\
\hline Italy & $564(81.15)$ & 427 (79.22) & 137 (87.82) & & \\
\hline other & $25(3.6)$ & $21(3.9)$ & $4(2.56)$ & & \\
\hline Males & $682(98.13)$ & 534 (99.07) & 148 (94.87) & 0.002 & \\
\hline Females & $13(1.87)$ & $5(0.93)$ & $8(5.13)$ & & \\
\hline $\mathrm{HbsAg}+$ & $30(6.22)$ & $24(5.81)$ & $6(8.7)$ & 0.42 & \\
\hline $\mathrm{HIV+}$ & $67(9.64)$ & $7(1.3)$ & $60(38.46)$ & $<0.001$ & \\
\hline
\end{tabular}

* Logistic regression model fitted with HCV infection as dependent variable and nationality and age as independent variables. 


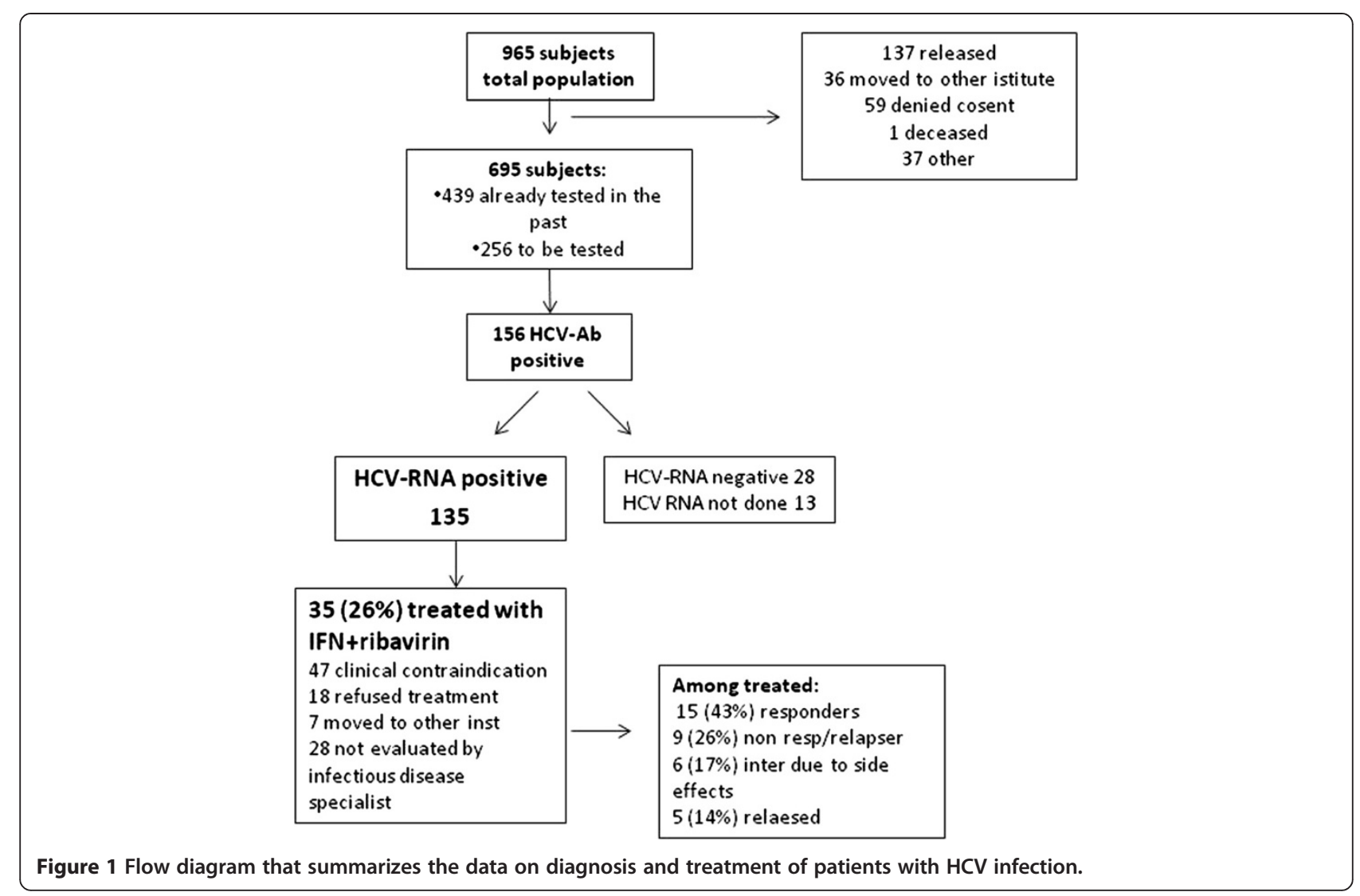

all inmates, these tests are not routinely performed on admission, or, even when performed, their results can be lost during prisoner's relocation.

Compared to Italian, foreign prisoners showed a lower prevalence of $\mathrm{HCV}$ infection, with African born patients, among foreigners, demonstrating the highest one, as published elsewhere [2]. Not surprisingly, women had a higher prevalence of $\mathrm{HCV}$ infection than men, as higher rates of Hepatitis B and C, HIV, and sexually transmitted infection, estimated at 2-10 times that of the general population were observed among imprisoned women, moreover, women had a significantly higher prevalence of all medical and psychiatric conditions and drug dependence when compared with imprisoned men [16].

In our study even if only $18 \%$ of total HCV-RNA positive inmates refused the treatment, 35 subjects (26\%) eventually were treated. Twenty per cent were untreated as they did not had specialist consultation and/or did not complete diagnostic procedures mainly due to organizing deficit and logistic problems. An interplay between medical and security staff should be implemented, in order to better organize the management of health needs of patients. Even if on 35 patients only, a $43 \%$ of SVR was observed, value that is comparable to data of SVR reported in the literature [17], confirming that in prison $\mathrm{HCV}$ treatment is an important option to be offered to inmates. HCV prognosis is worse if not appropriately treated, as evidenced by reduced mortality in patients successfully treated [18]. In a recent study conducted in Texas, end stage liver disease mortality in prison population is approximately three times higher than that of the general population, reflecting elevated rates of $\mathrm{HCV}$ and $\mathrm{HIV} / \mathrm{HCV}$ co-infection among prisoners [19]. Finally $14 \%$ of our treated subjects, released during treatment, were lost to follow up. As releasing from jail in Italy most of times take place with no forewarning, our patients were released without any therapeutic record and no practical possibility to continue treatment out of jail. We strongly suggest Italian correctional system to improve guidelines to release inmates with sanitary records so that they can continue any treatment once free.

The highest prevalence of HCV infection was observed among HIV positive patients. HIV-HCV-coinfected patients have higher levels of serum HCV RNA [20], an accelerated progression to end stage liver disease and a more rapid development of liver fibrosis and cirrhosis compared to those infected with HCV alone [21], moreover, when treated with antiretroviral treatment for HIV, they may show a decreased immune recovery [22]. Given the complex interplay of the two virus, HIV and HCV, it should be mandatory that HIV/HCV confected patients receive appropriate treatment for either HIV and HCV as soon as they need it. To further complicate $\mathrm{HCV}$ treatment in prison setting, an 
association between psychiatric disorders and hepatitis virus prevalence among inmates has been described [23], as result of intravenous drug abuse. Report of patients with chronic hepatitis $\mathrm{C}$ and psychiatric diseases treated in prison with interferon and ribavirin suggest that the treatment is possible and can be associated with discrete rate of virologic success $[6,7,9,24]$. An integrated approach with psychiatric support, has been described to favorably overcome the problem of psychiatric disorders in correctional settings [6] and should be advocated for all HCV patients with psychiatric co-morbidities.

The principal limitation of this study is represented by its being a single center study, so that the extent of generalizability of our findings to the prisoner's population thus remains unclear, despite the fact the Opera represents one of the larger Italian prisons. Data on $\mathrm{HCV}$ prevalence reported by other Italian authors are slightly higher than the ones reported in the present study [3,4]. The reason for this difference may be explained by the fact that the population detained in Milano Opera is different from those of smaller prisons, as in Milano Opera are detained those prisoner sentenced for a period longer than three years collected from all the Country for different major crimes (that are not strictly associated with illicit drug abuse) and in smaller prisons are detained prisoners for minor offences (usually intravenous drug abusers). Moreover, despite roughly $30 \%$ of patients restricted at the time of survey were not test for HCV infection, demographic differences between those tested and not tested were not observed, not altering the reproducibility of the data. Other studies $[3,4]$ report data on a subset of the examined population (less than 50\%) and this might have biased the reproducibility of the results. Another limitation is the absence of adequate follow up as a longer observation period, including also released patients, would have been useful to evaluate the response rate to treatment.

\section{Conclusion}

The present and other studies evidence that the proportion of patient in a prison setting receiving diagnosis and treatment for $\mathrm{HCV}$ infection remain low. The weight of $\mathrm{HCV}$ infection among HIV positive patients is worrisome, as they often can not be treated due severe immunosuppression and share the worse prognosis. An integrated health care taskforce should be encouraged and reinforced, as management of treatment of chronic hepatitis $\mathrm{C}$ requires the participation of specialists (hepatologist, infectious disease specialist, radiologist, psychiatrists) as well as primary care doctors and nurses.

\section{Abbreviations}

HCV: Hepatitis C virus; CDC: Center for disease control; IVDU: Intra venus drug abuser; HIV: Human immunodeficiency virus; SVR: Sustained virologic response; Ab: Antiboby.

\section{Competing interests}

$\mathrm{MB}$ received an unconditional grant from Shering-Plough for this research.

The authors declare that they have no competing interests.

\section{Authors' contributions}

MB, SN and ES conceived of the study, participated in study design, enrolled and treated patients and drafted the manuscript. AD and CT performed the statistical analysis and reviewed the manuscript. SFA P and RR treated patients and revised the manuscript. All authors read and approved the final manuscript.

\section{Author details}

${ }^{1}$ Clinica di Malattie Infettive, Fondazione IRCCS Policlinico San Matteo, Viale Camillo Golgi 19, 27100 Pavia, Italy. ${ }^{2}$ Servizio di Biometria e Statistica, Fondazione IRCCS Policlinico San Matteo, Viale Camillo Golgi 19, 27100 Pavia, Italy. ${ }^{3}$ Divisione di Malattie Infettive e Tropicali, Fondazione IRCCS Policlinico San Matteo, Viale Camillo Golgi 19, 27100 Pavia, Italy. ${ }^{4}$ Medicina Protetta Ospedale San Paolo-Milano, Milan, Italy.

Received: 27 May 2013 Accepted: 14 October 2013

Published: 20 October 2013

\section{References}

1. Spaulding AC, Weinbaum CM, Lau DT, Sterling R, Seeff LB, Margolis HS, Hoofnagle $\mathrm{JH}$ : A framework for management of hepatitis $\mathrm{C}$ in prisons. Ann Intern Med 2006, 144(10):762-769.

2. Saiz De La Hoya P, Marco A, García-Guerrero J, Rivera A: Hepatitis C and B prevalence in Spanish prisons. Eur J Clin Microbiol Infect Dis 2011, 30(7):857-862.

3. Babudieri $S$, Longo B, Sarmati $L$, Starnini G, Dori L, Suligoi B, Carbonara $S$, Monarca R, Quercia G, Florenzano G, Novati S, Sardu A, lovinella V, Casti A, Romano A, Uccella I, Maida I, Brunetti B, Mura MS, Andreoni M, Rezza G: Correlates of HIV, HBV, and HCV infections in a prison inmate population: results from a multicentre study in Italy. J Med Virol 2005, 76(3):311-317

4. Sabbatani S, Giuliani R, Fulgaro C, Paolillo P, Baldi E, Chiodo F: HIVAb, HCVAb and HBsAg seroprevalence among inmates of the prison of Bologna and the effetct of counselling on the compliance of proposed tests. Epidemiol Prev 2004, 28(3):163-168.

5. Decreto Ministero della Sanità: Approvazione del progetto obiettivo per la tutela della salute in ambito penitenziario; 2000. http://www.medicoeleggi. com/argomenti00/italia1/12447.htm.

6. Allen SA, Spaulding AC, Osei AM, Taylor LE, Cabral AM, Rich JD: Treatment of chronic hepatitis C in a state correctional facility. Ann Intern Med 2003, 138(3):187-190.

7. Maru DS, Bruce RD, Basu S, Altice FL: Clinical outcomes of hepatitis C treatment in a prison setting: feseability and effectiveness for challenging treatment populations. CID 2008, 47:952-961.

8. Marco A, Esteban Jl, Solé C, da Silva A, Ortiz J, Roget M, Sarriera C, Teixidó N, Guerrero RA, Caylà JA: Hepatitis C virus reinfection among prisoners with sustained virological response after treatment for chronic hepatitis C. J Hepatol 2013. in press.

9. Sabbatani S, Giuliani R, Manfredi R: Combined pegylated interferon and ribavirin for the management of chronic hepatitis $C$ in a prison setting. Braz J Infect Dis 2006, 10(4):274-278.

10. Ristretti news. http://www.ristretti.it/areestudio/statistiche/ricerca_statistica/ capitolo stranieri.pdf

11. Drug policy and harm reduction. http://ec.europa.eu/health/ ph_determinants/life_style/drug/documents/drug frep1.pdf.

12. Weinbaum C, Lyerla R, Margolis HS, Centers for Disease Control and Prevention: Prevention and control of infections with hepatitis viruses in correctional settings. MMWR Recomm Rep 2003, 52(RR-1):1-36.

13. Vescio MF, Longo B, Babudieri S, Starnini G, Carbonara S, Rezza G, Monarca $R$ : Correlates of hepatitis $C$ virus seropositivity in prison inmates: a metaanalysis. J Epidemiol Community Health 2008, 62:305-313.

14. Larney S, Kopinski H, Beckwith CG, Zaller ND, Jarlais DD, Hagan H, Rich JD, van den Bergh BJ, Degenhardt $L$ : The incidence and prevalence of hepatitis $C$ in prisons and other closed settings: results of a systematic review and meta-analysis. Hepatology 2013. in press.

15. Rantala M, van de Laar MJ: Surveillance and epidemiology of hepatitis B and C in Europe - a review. Euro Surveill 2008, 13:21. 
16. Colbert AM, Sekula LK, Zoucha R, Cohen SM: Health care needs of women immediately post-incarceration: a mixed methods study. Public Health Nurs 2013, 30(5):409-419.

17. Ford N, Kirby C, Singh K, Mills EJ, Cooke G, Kamarulzaman A, duCros P. Chronic hepatitis $C$ treatment outcomes in low- and middle-income countries: a systematic review and meta-analysis. Bull World Health Organ 2012, 90(7):540-550

18. van der Meer AJ, Veldt BJ, Feld JJ, Wedemeyer H, Dufour JF, Lammert F, Duarte-Rojo A, Heathcote EJ, Manns MP, Kuske L, Zeuzem S, Hofmann WP, de Knegt RJ, Hansen BE, Janssen HL: Association between sustained virological response and all-cause mortality among patients with chronic hepatitis C and advanced hepatic fibrosis. JAMA 2012, 308(24):2584-2593.

19. Baillargeon J, Soloway RD, Paar D, Giordano TP, Murray O, Grady J, Williams B, Pulvino J, Raimer BG: End-stage liver disease in a state prison population. Ann Epidemiol 2007, 17(10):808-813.

20. Sherman KE, O'Brien J, Gutierrez AG, Harrison S, Urdea M, Neuwald P, Wilber $\mathrm{J}$ : Quantitative evaluation of hepatitis $C$ virus RNA in patients with concurrent human immunodeficiency virus infection. J Clin Microbiol 1993, 31:2679-2682.

21. Martín-Carbonero L, Benhamou Y, Puoti M, Berenguer J, Mallolas J, Quereda C, Arizcorreta A, Gonzalez A, Rockstroh J, Asensi V, Miralles P, Laguno M, Moreno L, Girón JA, Vogel M, García-Samaniego J, Nuñez M, Romero M, Moreno $S$, de la Cruz JJ, Soriano V: Incidence and predictors of severe liver fibrosis in HIV infected patients with chronic hepatitis C: European Collaborative Study. Clin Infect Dis 2004, 38:128-133.

22. Seminari E, Tinelli C, Ravasi G, Ripamonti D, Ladisa N, Marino N, Sighinolfi L, Mondello P, Migliorino M, Carosi G, Maserati R: Hepatitis C infection on immune recovery in HIV-positive patients on successful HAART: the role of genotype 3. Curr HIV Res 2010, 8(3):186-193.

23. Baillargeon JG, Paar DP, Wu H, Giordano TP, Murray O, Raimer BG, Avery EN, Diamond PM, Pulvino JS: Psychiatric disorders, HIV infection and HIV/ hepatitis co-infection in the correctional setting. AIDS Care 2008, 20(1):124-129

24. Farley J, Vasdev S, Fischer B, Haydon E, Rehm J, Farley TA: Feasibility and outcome of HCV treatment in a Canadian federal prison population. Am J Public Health 2005, 95(10):1737-1739.

doi:10.1186/1471-2458-13-981

Cite this article as: Brandolini et al:: Prevalence and epidemiological correlates and treatment outcome of HCV infection in an Italian prison setting. BMC Public Health 2013 13:981.

\section{Submit your next manuscript to BioMed Central and take full advantage of:}

- Convenient online submission

- Thorough peer review

- No space constraints or color figure charges

- Immediate publication on acceptance

- Inclusion in PubMed, CAS, Scopus and Google Scholar

- Research which is freely available for redistribution 